\title{
Editorial \\ Meet Our International Editorial Consultants
}

\author{
Jennifer Lehmann \\ Co-editor, Children Australia
}

Children Australia has had the support and advice of many academic and professional practitioners over its many years of publication, with a number of people serving as Editorial Consultants. More recently, a number of international academics have joined our ranks, following in the footsteps of Nicola Taylor, Director of the Children's Issues Centre at the University of Otago, in Auckland, New Zealand, who was the first of our overseas academics. Nicola was the Guest Editor of a Special Issue some time ago, heralding what is now a more regular feature of the journal - encouraging collections of papers addressing specific topics.

We are now welcoming two more international academics - Professor Wynne Sandra Korr of the School of Social Work, University of Illinois, Illinois, USA, and Anna Gupta, Senior Lecturer in Social Work and Head of the Department of Health and Social Care at Royal Holloway, University of London, UK. In introducing Wynne and Anna to our readers, I decided to 'interview' each of them by Email, as well as including some background information about their work.

Professor Wynne Korr's PhD was in psychology and completed through the State University of New York at Buffalo. From 1980 to 1993, she taught at the Jane Addams College of Social Work, University of Illinois at Chicago. From 1994 to 2002, she held a professorial position at the School of Social Work, University of Pittsburgh, and was the co-director of the Center for Mental Health Services Research, while also directing the doctoral programme during her tenure at Pittsburgh. Her expertise is broad, with roles as a programme evaluator in the Illinois Department of Mental Health, and teaching courses in programme evaluation, services research and mental health policy. She has published on evaluation of mental health services, legal issues in mental health and other related topics.

Active in the Council on Social Work Education, Wynne was chair of the Commission on Accreditation and served as an ex-officio member of the Board of Directors. Previously, she served on the Women's Commission and the

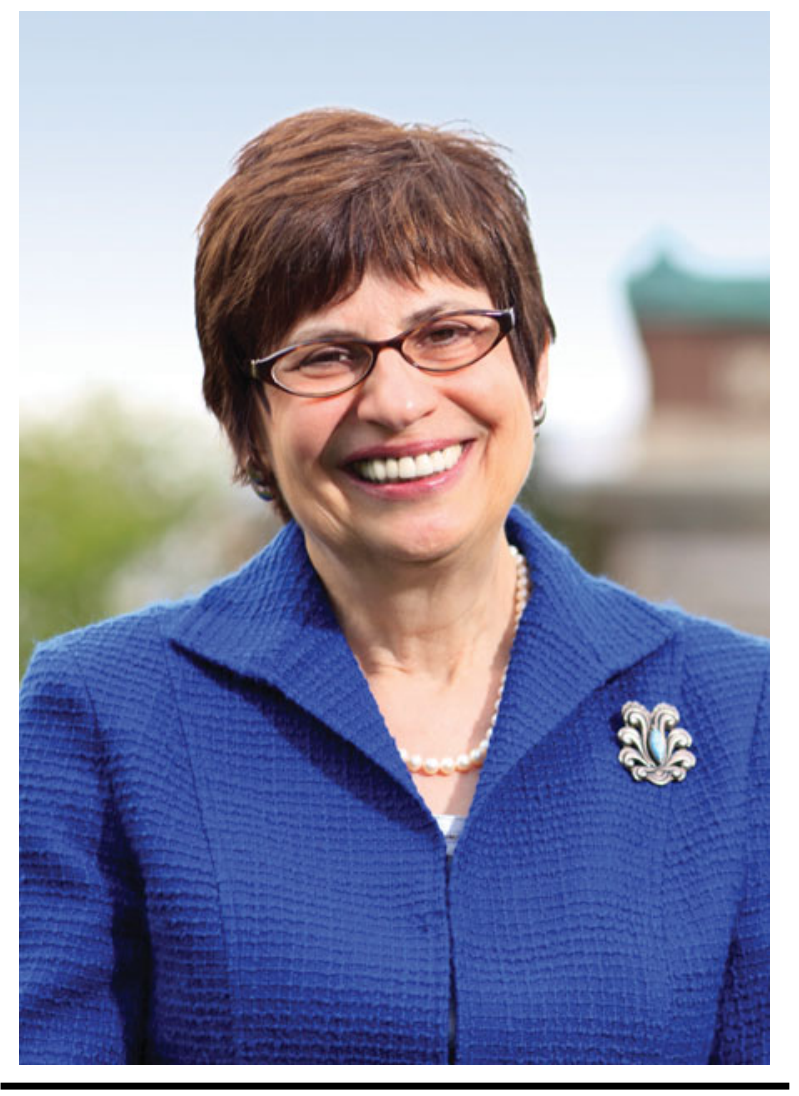

Professor Wynne Korr.

Commission on Publications and Media, and is past President of the St. Louis Group - the association of social work schools in major research universities. She is completing her term on the board of the Society for Social Work and Research. She is currently serving the local community as a member of the Board and the Community Impact Committee of United Way. With a focus on mental health policy and services, as well as social work education, Wynne's more 
recent research is on the dissemination of evidence-based research practice and on the financing of social services.

I asked Wynne what had drawn her from her studies in psychology to the profession of social work. Wynne told me she was working predominantly in community mental health and had begun working more and more with social workers. "I realised we shared in the use of an ecological framework" she said; and that "Social work values fit well with my personal commitment to social justice."

Over the years of teaching and research Wynne has, like many of us, moved across a number of special-interest areas and I asked her about how her work had unfolded. "I have had several special areas of interest" she said. "Improving services for people with severe mental illness was one for a long period of time. That led to my interest in public policy and in human rights frameworks. The latter led to my work with colleagues on children's rights. Now I am working on new approaches to addressing difficult social problems, including collective action and new financial frameworks." Wynne further commented that she finds herself regularly reading the journal Social Innovation Review.

I also wanted to explore what Wynne thought were the key issues facing social work and welfare practice in the USA at present, and asked her to comment in relation to gender issues and social work education. Wynne's response to this question echoed conversations about factors that are of concern to many social workers and teaching staff. She said, "As health care reform is implemented in the various states [of the USA] and communities, social workers need new skills in working in professional times, using evidence-based assessment and interventions, and in monitoring progress at the population level. Social work education needs to be both rooted in its traditional values, approaches and skills, but incorporating new ones rapidly. Social work education has to balance that tension between a generalist base and students' need for specialized knowledge and skills." This is clearly a challenge that will be with us for some time to come.

A list of some of Professor Wynne Korr's publications can be found at https://biomedicalprofiles.illinois.edu/ profilesweb/ProfileDetails.aspx?From $=$ SE\&Person $=1402$

Anna Gupta is a Senior Lecturer in Social Work in the Department of Social Work at Royal Holloway, University of London. She worked as a social worker and team manager in two London boroughs before joining the university in 1997. Throughout her academic career, Anna has maintained a link to practice in the family courts. She worked for 16 years as a self-employed Children's Guardian, and then more recently has been undertaking independent social work assessments.

Anna's busy career included being the director of the post-qualifying programmes for 10 years followed by the role of Head of Department in the Department of Social Work for 4 years until August 2013. Anna's current work at Royal Holloway involves teaching and assessing students on the Masters qualifying social work programme, as well as the post-qualifying programmes, which include the MSc in

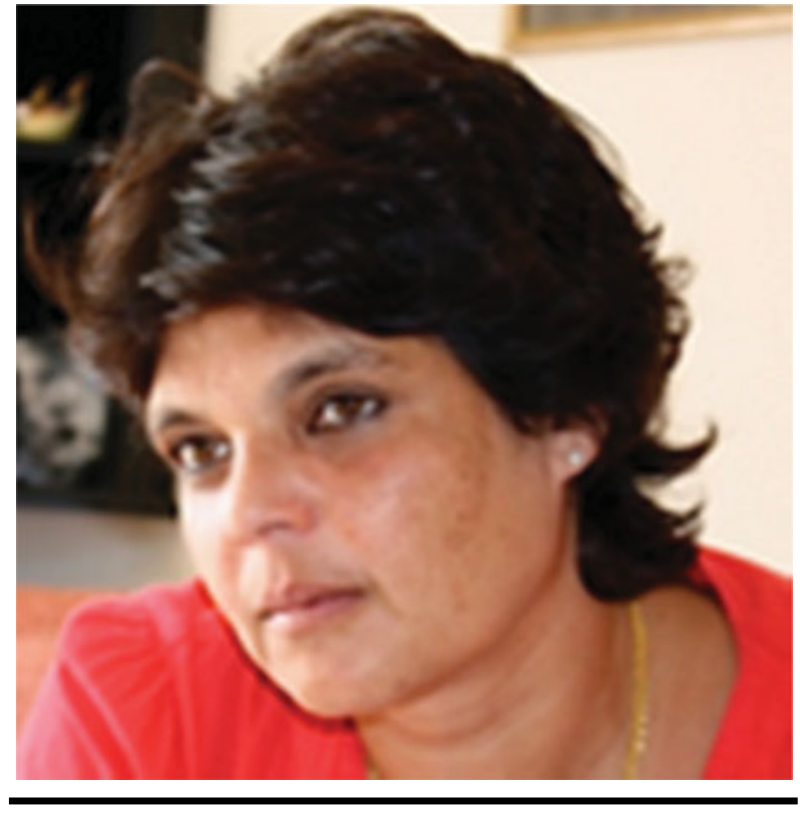

Anna Gupta.

Advanced Practice and professional doctorate programme. Anna has undertaken research and published articles on a range of subjects linked to child care and protection practice. Her particular interests include work in the family courts, poverty and social work, and practice with Black and minority ethnic children and families. More recently, Anna has been working on developing ideas about the use of the Capability Approach in social work. She is also part of an Economic and Social Research Council (ESRC) funded research seminar series looking at policy and practice with separated and unaccompanied children seeking asylum in Europe.

When asked what had drawn Anna to social work, she replied: "I trained as a social worker in Melbourne, at La Trobe University in the mid-eighties. I emigrated to Australia from India with my family when I was eleven and my father was very political with strong left-wing views, so I was brought up in an environment where the values of social justice, equality and human rights were central. These values drew me to social work. I saw it as a way, somewhat naively, to use my privilege and power to challenge injustice and champion the needs and rights of marginalised and oppressed people and communities."

Anna worked in Coburg, Melbourne, with Community Services Victoria (now Department of Human Services) for 18 months after graduating. She then travelled in Europe before settling in London. "I worked as a social worker and team manager in the Child Care Divisions of two London boroughs and have continued as an independent practitioner in the children/family courts whilst working at the university" she said. "My practice and academic interests have always been social work with children and families, including child protection, care proceedings and work 
with 'looked after' children. I am particularly interested in exploring what critical/anti-oppressive practice means within the field of child protection and statutory involvement of the state in private family life."

This led to her research interests, which include "... the impact of poverty and inequality on children and families involved in the child protection and family justice systems and the intersections with other social divisions, such as race and immigration status". Anna commented: "I am involved in a research project with ATD Fourth World, a human rights organisation working with families living in poverty who have experienced child protection interventions, as well as a research seminar series on unaccompanied and separated children seeking asylum. I am also working with colleagues in Holland and Germany, exploring the use of the Capability Approach (developed by Nobel prize winning economist Amartya Sen and philosopher and ethicist Martha Nussbaum) in social policy and social work."

When asked what she thinks are the current key issues facing social work, Anna said: "There are enormous changes going on in social work and welfare practice in the UK. For the past four and half years we have had a right-wing government that has made severe cuts to public spending, including welfare and family support services. Neoliberal ideology, including individual blaming of families for their socio-economic hardship, although apparent in some of the policies of New Labour, has significantly gathered pace under the coalition government. At the same time as the reduction in family support services, measures have been introduced to speed up the process of care proceedings and increase the number of non-consensual adoptions of children from care. Other changes that are of concern to myself and other social work academics and practitioners are moves to privatise Children's Services and undermine the generic nature of social work education. Recent policy initiatives include a Knowledge and Skills statement for child and family social work that defines the role narrowly in terms of primarily child protection work. From my perspective we are going through very uncertain and troubling times in social work and welfare practice in the UK, with issues of social justice and human rights increasingly absent from the mainstream discourse about social work."

As a qualified social worker, Anna brings to the role of Editorial Consultant with Children Australia her experience of child care social work and management, including work as a children's guardian and expert witness in public law family court proceedings. She has published work on various aspects of child welfare, including on working with families living in poverty, childhood neglect and work with Black and minority ethnic families. Anna is currently completing a British Association for the Study and Prevention of Child Abuse and Neglect (BASPCAN) study on child protection responses to forced marriage. The link to Anna's publications for those who wish to follow up on her research is: pure.royalholloway.ac.uk/.../en/persons/annagupta(0e6782f9-00e6-4cf7-bf64-e34eda2e3061)/projects

We are fortunate to have people of the calibre of Wynne and Anna joining our Editorial Consultants' group and are in the process of appointing several more international people as part of the process of establishing an international readership for the journal. I will bring further news of this in the next issue. 